Classification

Physics Abstracts

$61.72 \mathrm{~F}-75.50 \mathrm{~B}$

\title{
TEM-EDS Characterization of Second Phases in Ferritic Steels
}

\author{
Susanna Matera and Ettore Anelli \\ Centro Sviluppo Materiali S.P.A, P.O. Box 10747, Roma-EUR, Italy \\ (Received March 1; accepted June 14, 1995)
}

\begin{abstract}
TEM/STEM-EDS methods for the quantitative assessment of geometrical parameters, chemical composition and crystal structure of second phase particles are reviewed. Significant applications are discussed with regard to different ferritic steels: Interstitial Free (IF) steel for deep drawing, electrical $1 \% \mathrm{Si}$ steel and enameling steel. After short term isothermal annealing, a Ti-containing IF steel exhibited $\mathrm{Ti}(\mathrm{C}, \mathrm{N})$ precipitates that were finer and more frequent than $\mathrm{Ti}_{4} \mathrm{C}_{2} \mathrm{~S}_{2}$. $\mathrm{Ti}(\mathrm{C}, \mathrm{N})$ was a preferential site for $\mathrm{Ti}_{4} \mathrm{C}_{2} \mathrm{~S}_{2}$ nucleation. The experimental results were compared with calculations by a mathematical model of precipitation. Analysis of second phase particles in an electrical $1 \% \mathrm{Si}$ steel after isothermal annealing allowed evaluation of the inhibition factor for grain growth. The abnormal grain growth in this steel was mainly due to dissolution of $\mathrm{Cu}_{1.92} \mathrm{~S}$ and Ostwald ripening of $(\mathrm{Mn}, \mathrm{Cu}) \mathrm{S}$ and $\mathrm{Ti}(\mathrm{C}, \mathrm{N})$ with AlN. Quantitative investigation of precipitates in an enameling steel, together with hydrogen permeation measurements, showed that interstitial sites at the surface of coherent $\epsilon-\operatorname{Ti}(\mathrm{C}, \mathrm{N})$ precipitates act as efficient traps for hydrogen atoms.
\end{abstract}

\section{Introduction}

TEM/STEM-EDS techniques are a very useful tool for the quantitative analysis of fine second phases that play an important role in controlling the mechanical and magnetic properties of ferritic steels. Carbides and nitrides cause precipitation hardening [1] and, together with sulphides and oxides, influence hydrogen embrittlement [2]. In addition, second phases can influence grain size and texture, which affect strength, formability and magnetic properties.

In the present work methods for the measurement of mean size $(\bar{D})$, volume fraction $\left(F_{\mathrm{v}}\right)$, number per unit volume $\left(N_{\mathrm{v}}\right)$, chemical composition and crystal structure of fine second phase particles by TEM/STEM-EDS are reviewed and significant applications in steel metallurgy are discussed. Investigations were performed by a JEM 200CX TEM equipped with a $\mathrm{LaB}_{6}$ electron source, STEM attachment and EDS detector for high spatial resolution analysis of elements with atomic number $Z \geq 11$.

\section{Experimental Methods}

The characterization of second phases in steels requires the application of various TEM/STEM techniques on carbon extraction replicas and thin foils. 
2.1 Diffraction CONTRAST TEChNique - Selected Area Diffraction (SAD) patterns, dark and bright field images of second phases were applied to identify the crystal structure and orientation relationship with respect to the matrix. A previously developed on-line acquisition system [3] for automatic indexing of SAD patterns was applied.

2.2 High SPATIAL RESOlUtion EDS MicRoANALYSIS - The quantitative EDS microanalysis of fine second phases, with size in the range $20 \mathrm{~nm}$ to $300 \mathrm{~nm}$, was performed at $200 \mathrm{kV}$ on extraction replicas in order to avoid matrix contribution effects. The Cliff-Lorimer ratio method $[4,5]$ was applied. Carbon extraction replicas on graphite and aluminium grids were used to minimize spurious X-ray peaks. The electron beam current was chosen in order to have high X-ray count rates. However, 3000 counts per second were found to be a limit for the large particles to avoid excessive dead times. For a live time of $100 \mathrm{~s}$, the relative errors for peak intensity measurements were less than $13 \%$ (Fig. 1), even for small particles $(20 \mathrm{~nm}$ size) or low concentration values $(10-20 \mathrm{wt} \%)$.

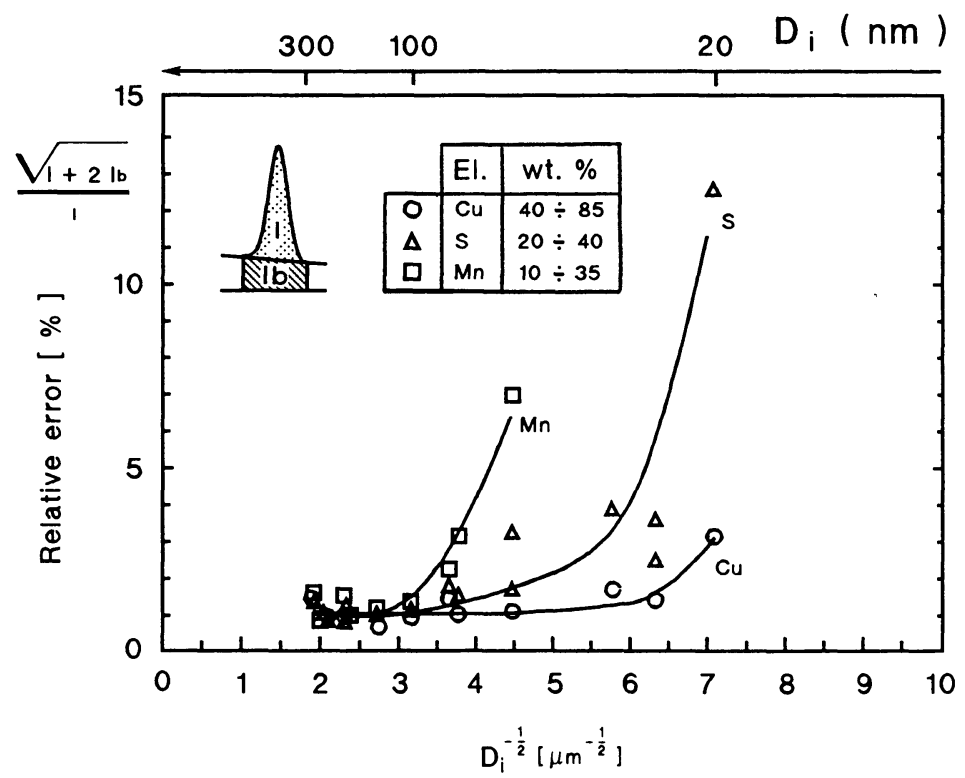

Fig. 1. - High spatial resolution EDS microanalysis of sulphides in extraction replicas. Effect of particle size $\left(D_{i}\right)$ on the relative error for peak intensity measurements. $\left(I=\right.$ net peak intensity; $I_{\mathrm{b}}=$ background intensity).

2.3 QuANTITATIVE Metallography - The determination of $F_{\mathrm{v}}$ and $N_{\mathrm{v}}$ was carried out on thin foils, as extraction replicas do not allow one to evaluate accurately the depth from which particles were extracted. TEM images of particles represent their area projection on a plane. Therefore the corrections of measured geometrical parameters, due to overlapping of particles and sectioning effects, are different from the case of optical metallography $[6,7]$.

The extraction replica technique was therefore selected as the sample preparation method for determining size distributions and $\bar{D}$ values, since sectioning effects are avoided and overlapping 
will be minimized. The high contrast was also helpful for accurate size measurements of a large number of particles $(\geq 1000)$.

Methods used for the evaluation of geometrical parameters are described in the Appendix.

\section{Second Phase Characterization}

Examples of second phase characterization will be presented for an interstitial free (IF) steel for deep drawing applications, an electrical $1 \%$ Si- steel and an enameling steel, whose chemical compositions are shown in Table I.

Table I. - Alloying elements (wt\%) in the steels.

\begin{tabular}{|c|cccccccc|}
\hline Steel & $\mathrm{C}$ & $\mathrm{Ti}$ & $\mathrm{N}$ & $\mathrm{S}$ & $\mathrm{Mn}$ & $\mathrm{Al}$ & $\mathrm{Si}$ & $\mathrm{Cu}$ \\
\hline IF & 0.0085 & 0.110 & 0.0025 & 0.0096 & 0.18 & 0.050 & 0.020 & 0.003 \\
Magnetic & 0.0030 & 0.001 & 0.0050 & 0.0070 & 0.27 & 0.230 & 0.950 & 0.170 \\
Enameling & 0.0481 & 0.300 & 0.0046 & 0.0100 & 0.47 & 0.040 & 0.048 & 0.002 \\
\hline
\end{tabular}

3.1 PRECIPITATION OF Ti COMPOUNDS IN IF STEEL - The excellent non ageing properties of IF steels depend on their low content of interstitial elements $(\mathrm{C}$ and $\mathrm{N})$ and on the proper addition of microalloying elements $(\mathrm{Ti}, \mathrm{Nb})$ which form highly stable phases with these solutes.

The isothermal precipitation of Ti compounds was investigated in the IF steel (Tab. I) in order to evaluate the reliability of a mathematical model in predicting nucleation and growth of second phases [8, 9].

Samples were annealed at $900{ }^{\circ} \mathrm{C}$ for holding times $1.2,2.4,12$ and $60 \mathrm{ks}$. The following second phases were identified:

fcc $\operatorname{Ti}(\mathrm{C}, \mathrm{N})$ with $a=0.433 \mathrm{~nm}$;

hcp $\mathrm{Ti}_{4} \mathrm{C}_{2} \mathrm{~S}_{2}$ with $a=0.3206 \mathrm{~nm}$ and $c=1.1190 \mathrm{~nm}$.

TiN and TiC are mutually miscible and could not be distinguished.

Some $\mathrm{Ti}_{4} \mathrm{C}_{2} \mathrm{~S}_{2}$ particles were found to be formed on $\mathrm{Ti}(\mathrm{C}, \mathrm{N})$ precipitates as shown in Figure 2. In such cases, when the sizes of the two types of particle were similar (Fig. 2a), the $S$ content in $\mathrm{Ti}_{4} \mathrm{C}_{2} \mathrm{~S}_{2}$ was underestimated because of the contribution of Ti from $\mathrm{Ti}(\mathrm{C}, \mathrm{N})$ (Tab. II). Nearly stoichiometric levels of $S$ were measured when the size of $\mathrm{Ti}_{4} \mathrm{C}_{2} \mathrm{~S}_{2}$ was larger than that of $\mathrm{Ti}(\mathrm{C}, \mathrm{N})$ (Fig. 2b, Tab. II). The nature of second phases and their relative frequency for increasing holding times are shown in Table III. The size distribution and values of $\bar{D}$ (Fig. 3), $F_{\mathrm{v}}$ and $N_{\mathrm{v}}$ (Tab. IV) were measured for the total population of second phase particles. The experimental geometrical parameters were compared with those calculated by a mathematical model [9] taking into account nucleation at dislocations and lattice defects. The interaction of $\mathrm{Ti}_{4} \mathrm{C}_{2} \mathrm{~S}_{2}$ with $\mathrm{Ti}(\mathrm{C}, \mathrm{N})$ was not considered in the calculation and both precipitation processes were assumed to be independent. The model predicted that $\mathrm{Ti}(\mathrm{C}, \mathrm{N})$ had higher frequency and smaller size than $\mathrm{Ti}_{4} \mathrm{C}_{2} \mathrm{~S}_{2}$ for short holding times $(\leq 2.4 \mathrm{ks})$, due to a faster nucleation rate, in agreement with experimental results (Tab. III).

The calculated mean sizes for $\mathrm{Ti}(\mathrm{C}, \mathrm{N})$ were consistent with experimental data (Fig. 4). However, the calculated values for long holding times predicted a faster rate of particle coarsening ( $\alpha$ coefficient) than the experimental one (Fig. 4). The preferential nucleation of $\mathrm{Ti}_{4} \mathrm{C}_{2} \mathrm{~S}_{2}$ on 

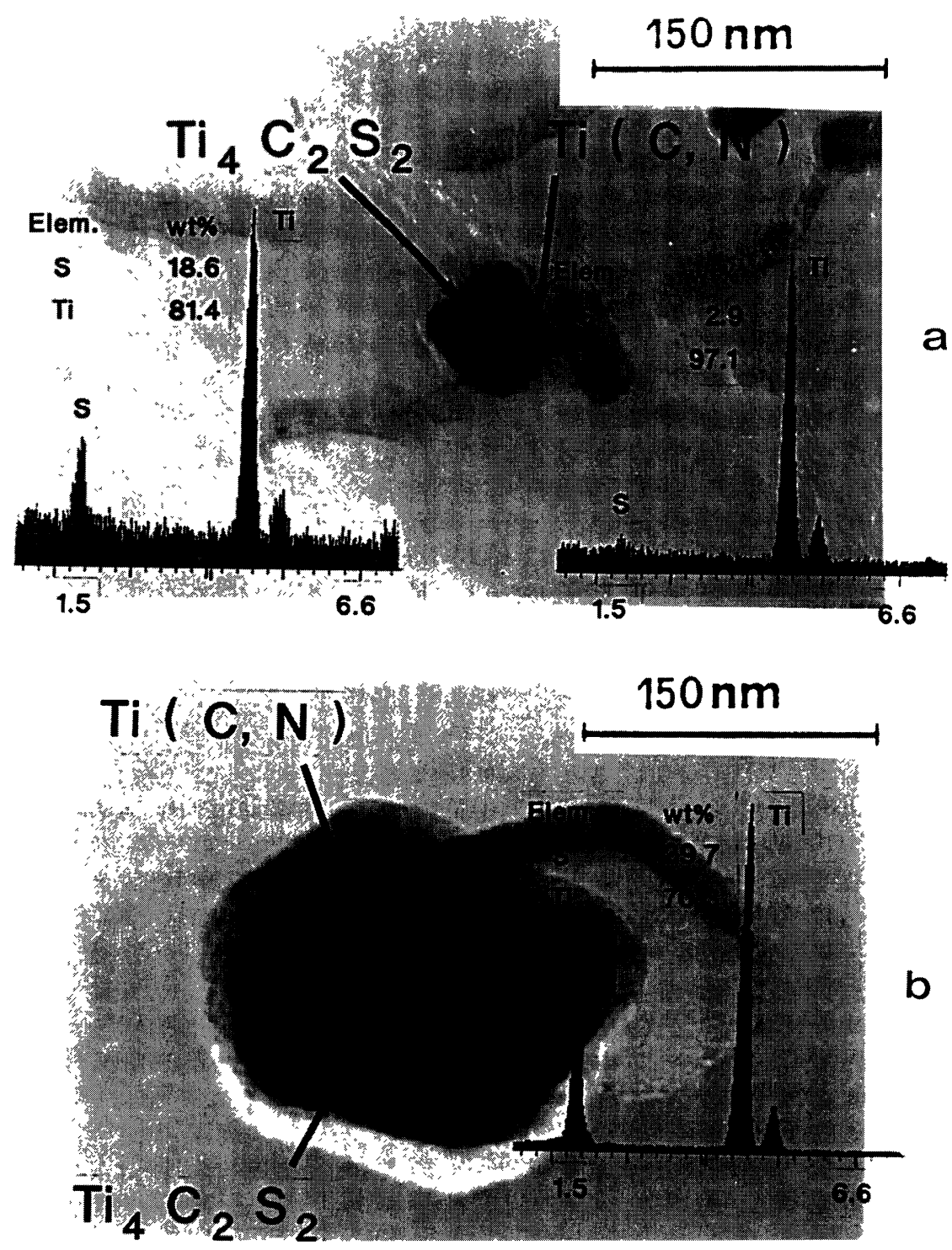

Fig. 2. $-\mathrm{Ti}_{4} \mathrm{C}_{2} \mathrm{~S}_{2}$ precipitation induced by $\mathrm{Ti}(\mathrm{C}, \mathrm{N})$ in the IF steel after isothermal annealing at $900{ }^{\circ} \mathrm{C}$ for $12 \mathrm{ks}$ : a) $\mathrm{Ti}(\mathrm{C}, \mathrm{N})$ and $\mathrm{Ti}_{4} \mathrm{C}_{2} \mathrm{~S}_{2}$ with similar size; b) $\mathrm{Ti}_{4} \mathrm{C}_{2} \mathrm{~S}_{2}$ larger than $\mathrm{Ti}(\mathrm{C}, \mathrm{N})$.

Ti(C,N), hindering the Ti(C,N) growth, can explain this behaviour. Predicted volume fractions of $\mathrm{Ti}(\mathrm{C}, \mathrm{N})$ were in agreement (Fig. 5) with experimental data relative to the total population of second phases. In fact, the volume fraction of $\mathrm{Ti}_{4} \mathrm{C}_{2} \mathrm{~S}_{2}$ precipitates is not significant for the IF steel considered. The calculated number per unit volume of $\mathrm{Ti}(\mathrm{C}, \mathrm{N})$ particles agreed well with experimental data (Fig. 6) for the whole range of annealing times. In practice, $\mathrm{Ti}(\mathrm{C}, \mathrm{N})$ as a preferential nucleation site for $\mathrm{Ti}_{4} \mathrm{C}_{2} \mathrm{~S}_{2}$ determined the total number of precipitates per unit volume.

3.2 Grain Growth IN MAGNETIC STEEL - The non oriented 1\%Si-steel sheets are produced for a variety of energy- efficient electrical machinery, where an alternating magnetic field must vary 
Table II. - Quantitative EDS microanalysis of second phases as a function of size for the IF steel after isothermal annealing at $900{ }^{\circ} \mathrm{C}$ for $12 \mathrm{ks}$.

\begin{tabular}{|c|c|c|c|}
\hline Particle Size [nm] & $\mathrm{S}[\mathrm{wt} \%]$ & $\mathrm{Ti}[\mathrm{wt} \%]$ & Prevalent precipitate \\
\hline 15 & 1.3 & 98.7 & $\mathrm{Ti}(\mathrm{C}, \mathrm{N})$ \\
40 & 13.8 & 86.2 & $\mathrm{Ti}(\mathrm{C}, \mathrm{N})+\mathrm{Ti}_{4} \mathrm{C}_{2} \mathrm{~S}_{2}$ \\
50 & 20.7 & 79.3 & $\mathrm{Ti}(\mathrm{C}, \mathrm{N})+\mathrm{Ti}_{4} \mathrm{C}_{2} \mathrm{~S}_{2}$ \\
55 & 2.0 & 98.0 & $\mathrm{Ti}(\mathrm{C}, \mathrm{N})$ \\
60 & 27.6 & 72.4 & $\mathrm{Ti}_{4} \mathrm{C}_{2} \mathrm{~S}_{2}$ \\
75 & 24.1 & 75.9 & $\mathrm{Ti}_{4} \mathrm{C}_{2} \mathrm{~S}_{2}$ \\
80 & 28.0 & 72.0 & $\mathrm{Ti}_{4} \mathrm{C}_{2} \mathrm{~S}_{2}$ \\
180 & 28.7 & 70.3 & $\mathrm{Ti}_{4} \mathrm{C}_{2} \mathrm{~S}_{2}$ \\
\hline
\end{tabular}

Table III. - Second phases identified in the IF steel after isothermal annealing at $900{ }^{\circ} \mathrm{C}$ for different holding times.

\begin{tabular}{|c|c|c|c|c|c|c|}
\hline \multirow{2}{*}{$\begin{array}{c}\text { Holding } \\
\text { time at } \\
900^{\circ} \mathrm{C}\end{array}$} & \multicolumn{2}{|c|}{$\mathrm{Ti}(\mathrm{C}, \mathrm{N})$} & \multicolumn{2}{|c|}{$\mathrm{Ti}(\mathrm{C}, \mathrm{N})+\mathrm{Ti}_{4} \mathrm{C}_{2} \mathrm{~S}_{2}$} & \multicolumn{2}{c|}{$\mathrm{Ti}_{4} \mathrm{C}_{2} \mathrm{~S}_{2}$} \\
\cline { 2 - 7 }$[\mathrm{ks}]$ & $\begin{array}{c}\text { Range } \\
{[\mathrm{nm}]}\end{array}$ & $\begin{array}{c}\text { Relative } \\
\text { Frequency }\end{array}$ & $\begin{array}{c}\text { Size } \\
\text { Range } \\
{[\mathrm{nm}]}\end{array}$ & $\begin{array}{c}\text { Relative } \\
\text { Frequency }\end{array}$ & $\begin{array}{c}\text { Size } \\
\text { Range } \\
{[\mathrm{nm}]}\end{array}$ & $\begin{array}{c}\text { Relative } \\
\text { Frequency }\end{array}$ \\
\hline 1.2 & $5-30$ & very frequent & $/$ & absent & $150-500$ & very rare \\
2.4 & $5-100$ & very frequent & $/$ & absent & $200-500$ & very rare \\
12 & $/$ & absent & $5-200$ & very frequent & $200-1000$ & very rare \\
60 & $/$ & absent & $5-200$ & frequent & $200-1000$ & rare \\
\hline
\end{tabular}

isotropically. These materials are required to have a sharp grain size distribution centred at 120$130 \mu \mathrm{m}$ and a controlled texture characterized by the direction of easy magnetization, $<100>$, lying in the plane of the sheet.

The isothermal evolution of second phases in the magnetic steel (Tab. I) was investigated in order to evaluate the inhibition effect on grain growth. The second phase parameters are important in controlling abnormal grain growth process and the consequent texture development. Different types of second phases such as sulphides and nitrides were identified in samples annealed at $850^{\circ} \mathrm{C}$ for holding times from 0.18 to $864 \mathrm{ks}$ :

hcp $\mathrm{Cu}_{1.92} \mathrm{~S}$ with $a=1.135 \mathrm{~nm}, c=1.3506 \mathrm{~nm}$,

fcc (Mn,Cu)S with $a=0.5224 \mathrm{~nm}$,

hcp AlN with $a=0.3111 \mathrm{~nm}$ and $c=0.4978 \mathrm{~nm}$,

fcc TiN with $a=0.424 \mathrm{~nm}$ 

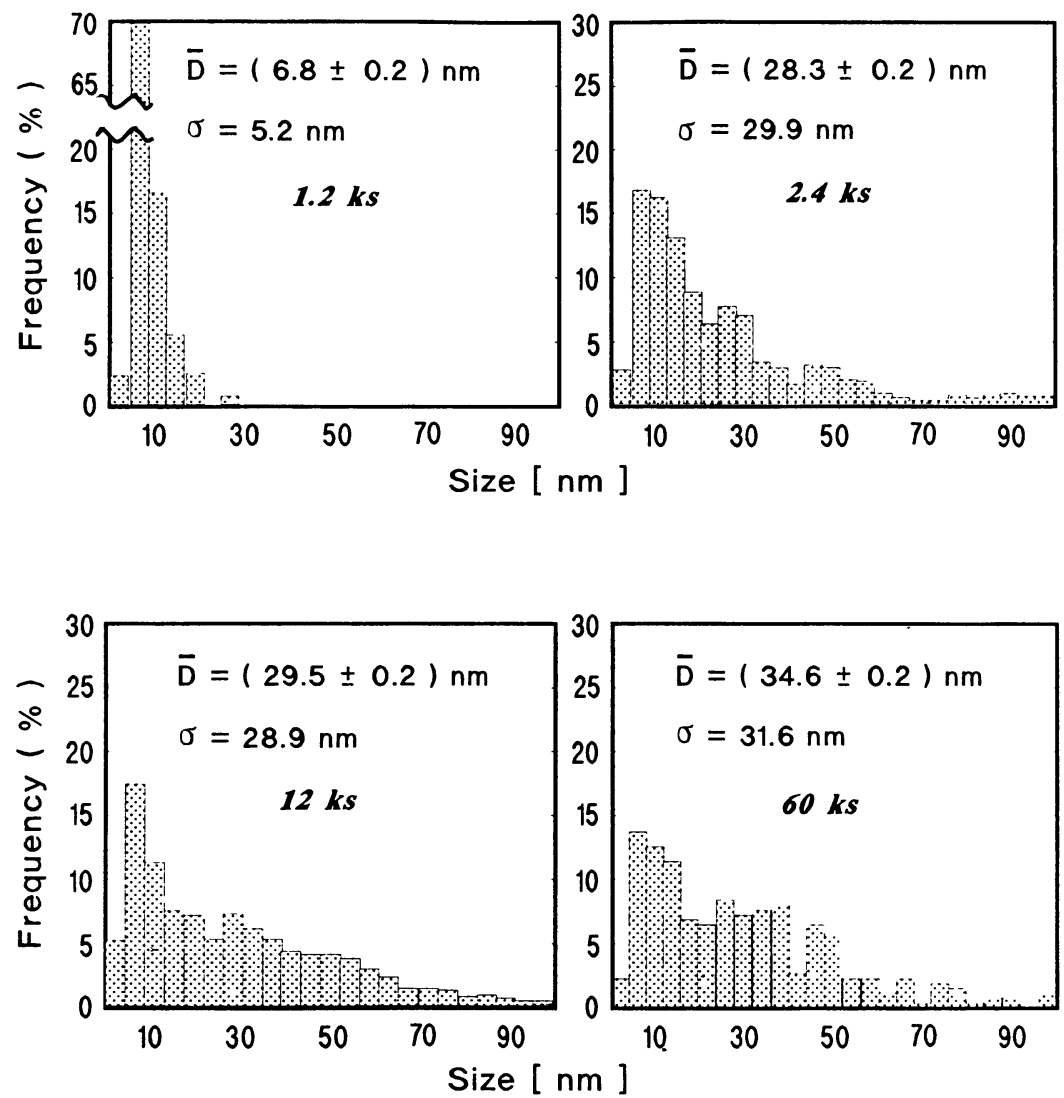

Fig. 3. - Experimental size distribution of $\mathrm{Ti}(\mathrm{C}, \mathrm{N})+\mathrm{Ti}_{4} \mathrm{C}_{2} \mathrm{~S}_{2}$ measured in the IF steel after isothermal annealing at $900^{\circ} \mathrm{C}$ for increasing holding times.

Table IV. - Volume fraction $\left(F_{\mathrm{v}}\right)$ and number per unit volume $\left(N_{\mathrm{v}}\right)$ of second phases in the IF steel after isothermal annealing at $900{ }^{\circ} \mathrm{C}$ for different holding times. Foil thickness, $t$, and foil thickness to particle mean size ratio, $t / \bar{D}$, are also shown.

\begin{tabular}{|c|c|c|c|c|}
\hline $\begin{array}{c}\text { Holding time at } \\
900^{\circ} \mathrm{C}\end{array}$ & $F_{\mathrm{V}}$ & $N_{\mathrm{v}}\left[\mathrm{mm}^{-3}\right]$ & $\begin{array}{c}\text { Foil Thickness* } \\
{[\mathrm{nm}]}\end{array}$ & $\frac{t}{\bar{D}}$ \\
\hline $\mathrm{ks}]$ & $(7 \pm 6) 10^{-5}$ & $(3 \pm 1) 10^{16}$ & $\mathrm{t}^{\mathrm{cc}}=(180 \pm 60)$ & 25 \\
1.2 & $(6 \pm 2) 10^{-4}$ & $(3.8 \pm 0.9) 10^{16}$ & $\mathrm{t}^{\mathrm{tf}}=(276 \pm 55)$ & 10 \\
2.4 & $(1.9 \pm 0.9) 10^{-4}$ & $(5 \pm 1) 10^{16}$ & $\mathrm{t}^{\mathrm{tf}}=(153 \pm 30)$ & 5 \\
12 & $(4 \pm 3) 10^{-3}$ & $(1.4 \pm 0.5) 10^{16}$ & $\mathrm{tcc}^{\mathrm{cc}}=(200 \pm 70)$ & 6 \\
\hline 60 &
\end{tabular}

$* \mathrm{t}^{\mathrm{tf}}$ and $\mathrm{t}^{\mathrm{cc}}$ refer to thickness measurements by the fringe and contamination cone methods respectively (see Appendix). 


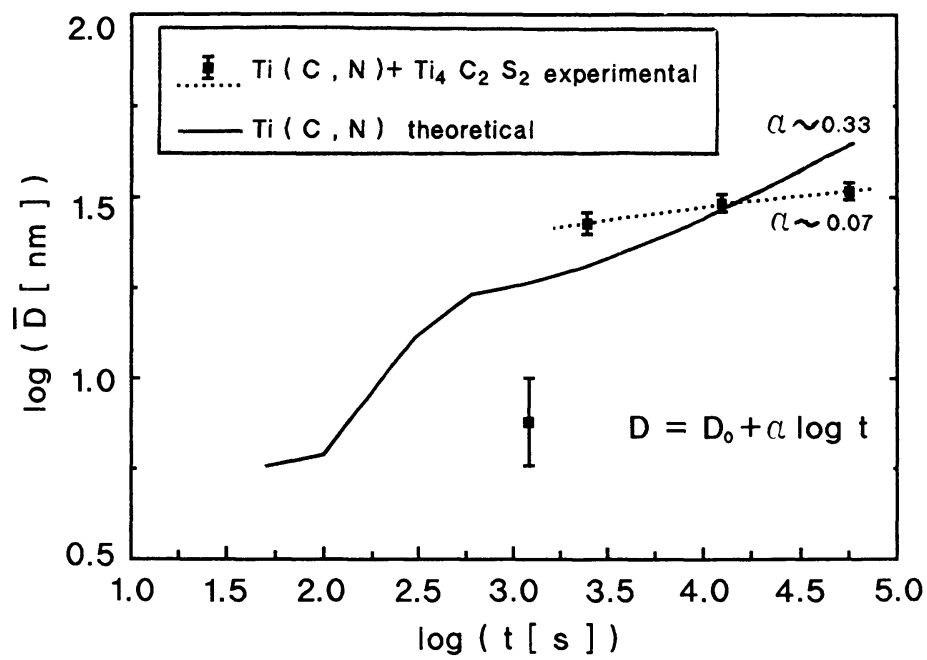

Fig. 4. - Comparison of experimental and calculated values of $\bar{D}$ as a function of holding time in the IF steel.

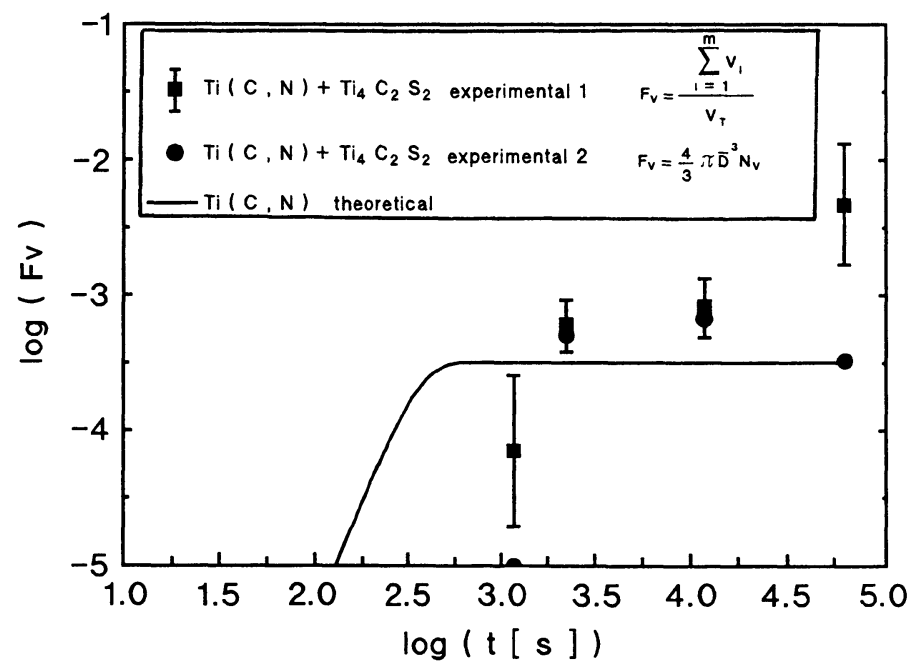

Fig. 5. - Comparison of experimental and calculated values of $F_{\mathrm{v}}$ as a function of holding time for the IF steel.

The nature of second phases and their relative frequency for increasing holding times are shown in Table V. A holding time of $18 \mathrm{ks}$ at $850{ }^{\circ} \mathrm{C}$ caused $\mathrm{Cu}_{1.92} \mathrm{~S}$ dissolution and the precipitation of TiN; for holding times longer than $18 \mathrm{ks}$ Ostwald ripening of $(\mathrm{Mn}, \mathrm{Cu}) \mathrm{S}$ and TiN, AlN was observed.

Measurements of $\bar{D}$ and $F_{\mathrm{v}}$ parameters with reference to the total population of second phases were performed to evaluate the grain growth inhibition factor, $I_{z}$, defined as follows [10]:

$$
I_{z}=12 \frac{F_{\mathrm{v}}}{\pi \bar{D}}
$$




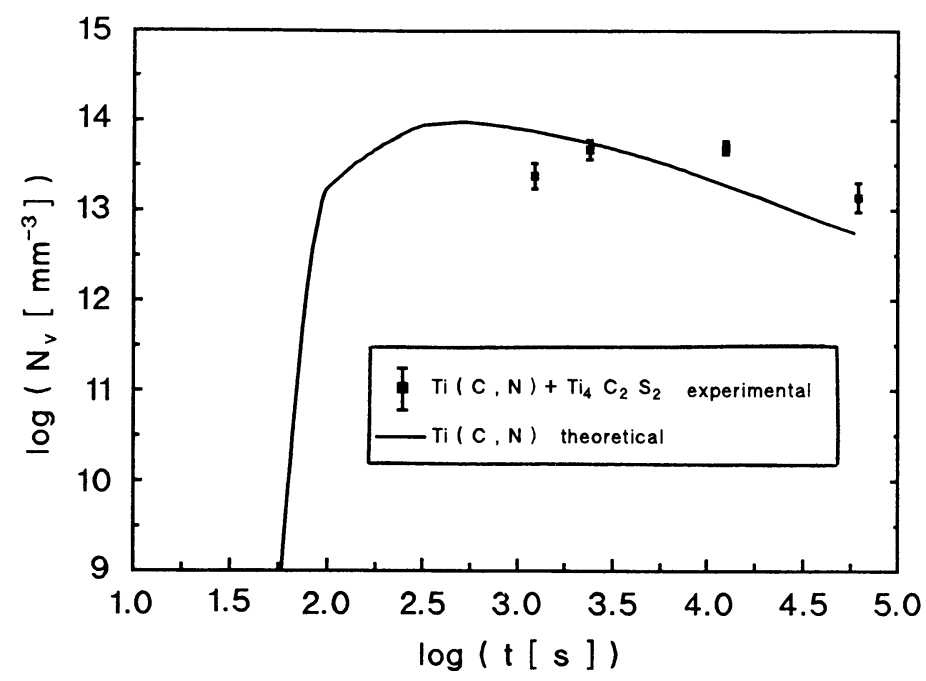

Fig. 6. - Comparison of experimental and calculated values of $N_{\mathrm{v}}$ as a function of holding time for the IF steel.

Table V. - Second phases identified in magnetic steel after isothermal annealing at $850{ }^{\circ} \mathrm{C}$ for different holding times.

\begin{tabular}{|c|c|c|c|c|c|c|c|c|}
\hline \multirow{3}{*}{$\begin{array}{c}\text { Holding } \\
\text { time at } \\
850^{\circ} \mathrm{C} \\
{[\mathrm{ks}]} \\
\end{array}$} & \multicolumn{2}{|c|}{$\mathrm{Cu}_{1.92} \mathrm{~S}$} & \multicolumn{2}{|c|}{$(\mathrm{Mn}, \mathrm{Cu}) \mathrm{S}$} & \multicolumn{2}{|c|}{ AlN } & \multicolumn{2}{|r|}{ TiN } \\
\hline & Size & Relative & Size & Relative & Size & Relative & Size & Relative \\
\hline & $\begin{array}{c}\text { Range } \\
{[\mathrm{nm}]}\end{array}$ & Frequency & $\begin{array}{c}\text { Range } \\
{[\mathrm{nm}]}\end{array}$ & requency & $\begin{array}{c}\text { Range } \\
{[\mathrm{nm}]}\end{array}$ & requency & $\begin{array}{c}\text { Range } \\
{[\mathrm{nm}]}\end{array}$ & Frequency \\
\hline 0.18 & $5-20$ & very frequent & $\begin{array}{l}100- \\
250\end{array}$ & frequent & $500-2000$ & rare & I & absent \\
\hline 18 & I & absent & $\begin{array}{l}120- \\
270\end{array}$ & frequent & 300 & rare & $30-150$ & rare \\
\hline 864 & I & absent & $\begin{array}{l}150- \\
400\end{array}$ & frequent & 300 & rare & $30-150$ & frequent \\
\hline
\end{tabular}

The measured precipitate parameters and $I_{z}$ values for samples treated for $0.18 \mathrm{ks}$ and $864 \mathrm{ks}$ are compared in Table VI. A significant decrease in $I_{z}$ is observed for long holding times.

These results, combined with the initial grain size distribution and texture were used as input data to simulate grain growth evolution by another mathematical model [11]. The observed abnormal grain growth of $\{110\}$ and $\{111\}$ grains was explained by considering two inhibition decreases at different annealing times: a fast decrease due to $\mathrm{Cu}_{1.92} \mathrm{~S}$ dissolution, and a successive slow one due to Ostwald ripening of the $(\mathrm{Mn}, \mathrm{Cu}) \mathrm{S}$ and TiN with AlN. 
Table VI. - Mean size $(\bar{D})$, volume fraction $\left(F_{\mathrm{v}}\right)$ and grain growth inhibition factor $\left(I_{z}\right)$ of second phases in the magnetic steel after isothermal annealing at $850^{\circ} \mathrm{C}$ for different holding times.

\begin{tabular}{|c|c|c|c|c|c|}
\hline $\begin{array}{c}\text { Holding time at } \\
900^{\circ} \mathrm{C}[\mathrm{ks}]\end{array}$ & $\bar{D}[\mathrm{~nm}]$ & $F_{\mathrm{V}}$ & $I_{Z}\left[\mathrm{~mm}^{-1}\right]$ & $\begin{array}{c}\text { Foil Thickness } \\
{[\mathrm{nm}]}\end{array}$ & $\frac{t}{\bar{D}}$ \\
\hline 0.18 & $(31 \pm 2)$ & $(2.0 \pm 0.6) 10^{-3}$ & $(247 \pm 60)$ & $\mathrm{t}^{\mathrm{tf}_{=}(240 \pm 60)}$ & 10 \\
\hline 864 & $(47 \pm 2)$ & $(7 \pm 2) 10^{-4}$ & $(57 \pm 14)$ & $\mathrm{t}^{\mathrm{tf}}=(220 \pm 55)$ & 5 \\
\hline
\end{tabular}

* $\mathrm{t}^{\mathrm{tf}}$ refers to thickness measurement by the fringe method (see Appendix).

3.3 HYDROGEN TRAPPING IN ENAMELING STEELS - The diffusivity and solubility of hydrogen in enameling steels are influenced by the presence of second phases which behave as traps for hydrogen atoms.

The geometrical parameters and crystal structure of second phases in an enameling steel (Tab. I) were related to hydrogen permeation measurements in order to evaluate the hydrogen trapping capability of second phases. Hydrogen permeation curves and trapped hydrogen concentrations were measured by means of the electrochemical method [12] using a $0.1 \mathrm{M} \mathrm{NaOH}$ solution and the technique reported in reference [13].

Three types of precipitates were present in the enameling steel:

$\epsilon-\operatorname{Ti}(\mathrm{C}, \mathrm{N})$ coherent with ferritic matrix $(\alpha-\mathrm{Fe})$ : Simple Tetragonal with $a=0.429 \mathrm{~nm}$ and $c=$ $0.561 \mathrm{~nm}$. The $\mathrm{SAD}$ pattern of $\epsilon-\operatorname{Ti}(\mathrm{C}, \mathrm{N})$ showed the following orientation relationship (Fig. 7):

$[\overline{1} 11]_{\alpha-\mathrm{Fe}} \|[342]_{\epsilon-\mathrm{Ti}(\mathrm{C}, \mathrm{N})}$

$(110)_{\alpha-\mathrm{Fe}} \|(\overline{22} 1)_{\epsilon-\mathrm{Ti}(\mathrm{C}, \mathrm{N})}$

$\operatorname{Ti}(\mathrm{C}, \mathrm{N})$ incoherent with ferritic matrix: fcc with $a=0.433 \mathrm{~nm}$;

TiS incoherent with ferritic matrix: hcp with $a=0.342 \mathrm{~nm}$ and $c=2.640 \mathrm{~nm}$.

Table VII. - Second phases identified in the enameling steel.

\begin{tabular}{|c|c|c|c|c|c|}
\hline \multicolumn{2}{|c|}{$\varepsilon-\operatorname{Ti}(\mathrm{C}, \mathrm{N})$} & \multicolumn{2}{c|}{$\mathrm{Ti}(\mathrm{C}, \mathrm{N})$} & \multicolumn{2}{c|}{ TiS } \\
\hline $\begin{array}{c}\text { Size } \\
\text { Range } \\
{[\mathrm{nm}]}\end{array}$ & Relative & $\begin{array}{c}\text { Size } \\
\text { Fange }\end{array}$ & $\begin{array}{c}\text { Relative } \\
\text { Frequency } \\
{[\mathrm{nm}]}\end{array}$ & $\begin{array}{c}\text { Size } \\
\text { Range } \\
{[\mathrm{nm}]}\end{array}$ & $\begin{array}{c}\text { Relative } \\
\text { Frequency }\end{array}$ \\
\hline $5-30$ & very frequent & $50-200$ & rare & $100-300$ & very rare \\
\hline
\end{tabular}

However, incoherent $\mathrm{Ti}(\mathrm{C}, \mathrm{N})$ and TiS precipitates were not frequently detected (Tab. VII). The estimated numerical fraction of incoherent $\mathrm{Ti}(\mathrm{C}, \mathrm{N})$ was less than $2 \%$ (Fig. 8). 


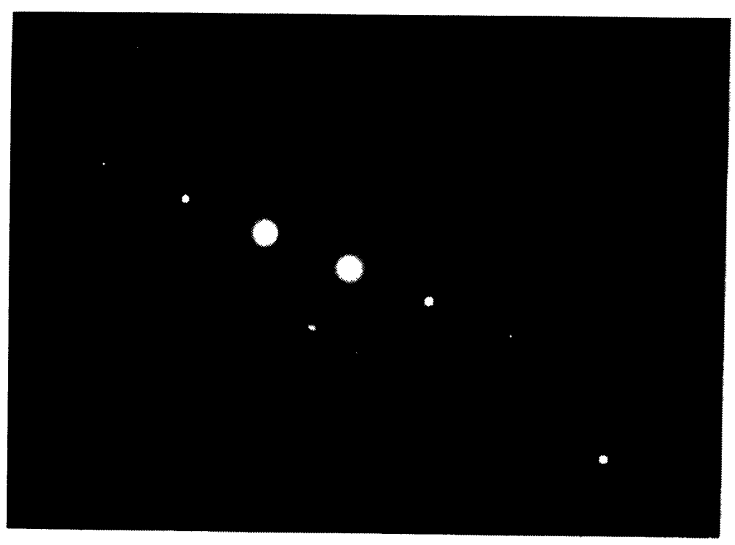

a

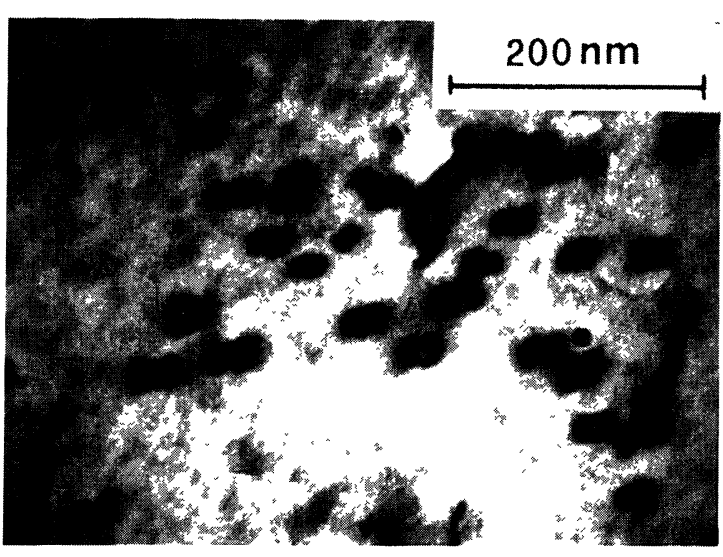

C

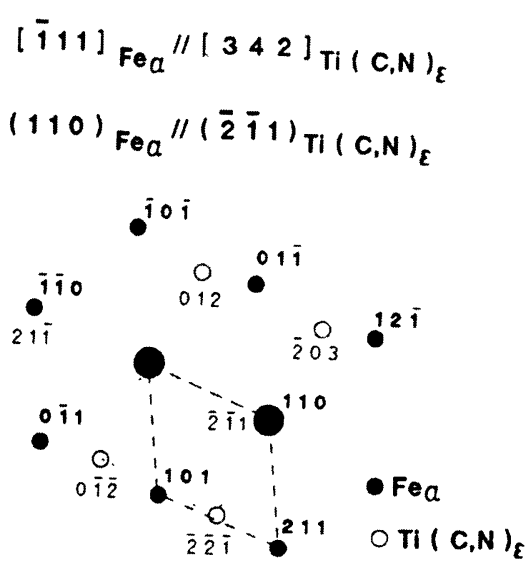

b

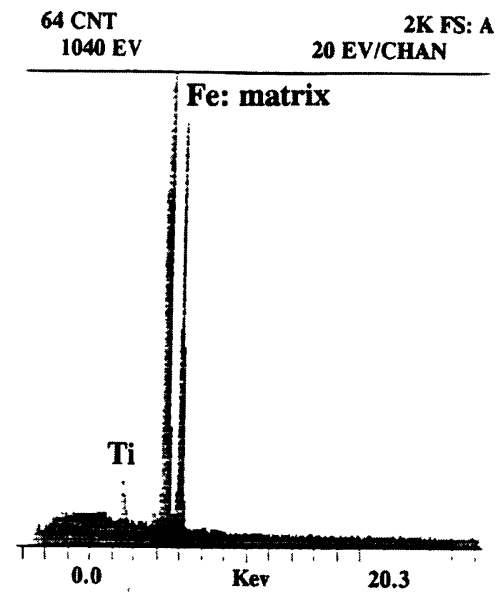

d

Fig. 7. - Second phases analysis in a thin foil of the enameling steel. Coherent $\epsilon-\operatorname{Ti}(C, N)$ in the enameling steel: a) SAD pattern; b) indexing of SAD pattern (Simple Tetragonal: $a=0.429 \mathrm{~nm}, c=0.561 \mathrm{~nm}$ ) and orientation relationship with matrix; c) Bright Field Image; d) EDS microanalysis.

These results, combined with hydrogen permeation tests, showed that hydrogen trapping is mainly due to coherent $\epsilon$-Ti(C,N).

Assuming that the whole surface area $(\bar{S})$ of the coherent $\epsilon$-Ti $(C, N)$ precipitates can contribute to hydrogen trapping and considering the average area $(\bar{a})^{2}=\left(a^{2}+2 a c\right) / 3=0.222 \mathrm{~nm}^{2}$ of one face of the tetragonal unit cell, the number, $k$, of hydrogen atoms for unit cell is calculated from the following equation [14]:

$$
k=\frac{(\bar{a})^{2} N_{\mathrm{I}}}{\bar{S} N_{\mathrm{v}}}
$$

where $N_{\mathrm{I}}$ is the number of trapped hydrogen atoms per unit volume, evaluated by permeation measurements, and $N_{\mathrm{v}}$ is the number per unit volume of coherent $\epsilon-\mathrm{Ti}(\mathrm{C}, \mathrm{N})$. TEM measurements (Tab. VIII) and permeation results $\left(N_{\mathrm{I}}=7 \times 10^{15} \mathrm{~mm}^{-3}\right)$ allowed us to estimate a $k$ value of about 1 , which is the number of interstitial sites of the tetragonal unit cell. 


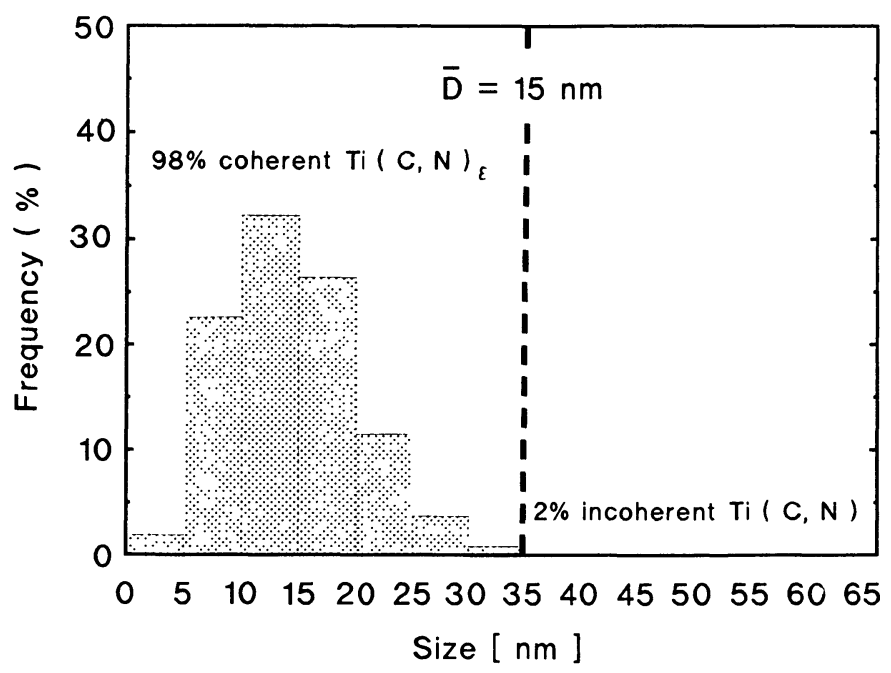

Fig. 8. - Size distribution and $\bar{D}$ of $\mathrm{Ti}(\mathrm{C}, \mathrm{N})$ in the enameling steel.

Table VIII. - Mean size $(\bar{D})$, surface area $\bar{S}$ and number per unit volume $\left(N_{\mathrm{v}}\right)$ of coherent $\epsilon-\mathrm{Ti}(\mathrm{C}, \mathrm{N})$ precipitates in the enameling steel.

\begin{tabular}{|c|c|c|c|c|}
\hline $\bar{D} \mathrm{~nm}$ & $\bar{S}\left[\mathrm{~nm}^{2}\right]$ & $N_{\mathrm{V}}\left[\mathrm{mm}^{-3}\right]$ & $\begin{array}{c}\text { Foil Thickness* } \\
{[\mathrm{nm}]}\end{array}$ & $\frac{t}{\bar{D}}$ \\
\hline$(15 \pm 2)$ & $(707 \pm 94)$ & $(2.0 \pm 0.2) 10^{12}$ & $t^{\mathrm{tf}}=(120 \pm 30)$ & 10 \\
\hline
\end{tabular}

$* \mathrm{t}^{\mathrm{tf}}$ refers to thickness measurement by the fringe method (see Appendix).

\section{Conclusions}

TEM/STEM-EDS techniques allow a quantitative assessment of geometrical parameters, chemical composition and crystal structure of second phases in steels.

Regarding the Ti-IF steel, these methods indicate that, after isothermal annealing, $\mathrm{Ti}(\mathrm{C}, \mathrm{N})$ precipitates are finer and more frequent than $\mathrm{Ti}_{4} \mathrm{C}_{2} \mathrm{~S}_{2}$ for short holding times, in agreement with mathematical model calculations which predicted a fast $\mathrm{Ti}(\mathrm{C}, \mathrm{N})$ nucleation rate. $\mathrm{Ti}(\mathrm{C}, \mathrm{N})$ is a preferential site for $\mathrm{Ti}_{4} \mathrm{C}_{2} \mathrm{~S}_{2}$ nucleation and determines the value of $N_{\mathrm{v}}$ for all precipitates of the type $\mathrm{Ti}(\mathrm{C}, \mathrm{N})+\mathrm{Ti}_{4} \mathrm{C}_{2} \mathrm{~S}_{2}$.

The abnormal grain growth, observed for an electrical $1 \% \mathrm{Si}$ steel, is mainly due to dissolution of $\mathrm{Cu}_{1.92} \mathrm{~S}$ and Ostwald ripening of $(\mathrm{Mn}, \mathrm{Cu}) \mathrm{S}, \mathrm{Ti}(\mathrm{C}, \mathrm{N})$ with $\mathrm{AlN}$ second phases.

Quantitative investigation of precipitates present in an enameling steel, combined with hydrogen permeation measurements, shows that interstitial sites at the surface of coherent $\epsilon-\mathrm{Ti}(\mathrm{C}, \mathrm{N})$ precipitates have a high probability of occupancy by hydrogen atoms. 


\section{Appendix}

A.1 Measurements of Geometrical Parameters. - Size distribution, and mean size, $\bar{D}$, were measured on extraction replicas. The size of the $i^{\text {th }}$ particle, $D_{i}$, was evaluated as:

$$
D_{i}=\frac{a_{i}+b_{i}}{2} \pm \Delta D_{i}
$$

with

$$
\Delta D_{i}=\left(\Delta a_{i}+\Delta b_{i}\right) / 2 \text { and } \Delta a_{i}=\Delta b_{i} \cong \pm 2 \mathrm{~nm}
$$

where $a_{i}$ and $b_{i}$ are the maximum and the minimum sizes of the $i^{\text {th }}$ particle, respectively. These sizes were accurately measured on TEM micrographs by a graduated eye piece or an automatic image analyzer equipped with a macroviewer.

The mean size, $\bar{D}$, was calculated as the numerical average of $D_{i}$ :

$$
\bar{D}=\frac{\sum_{i=1}^{n} D_{i}}{n} \pm \Delta \bar{D} \text { with } \Delta \bar{D}=\frac{\sum_{i=1}^{n} \Delta D_{i}}{n}
$$

where $n$ is the total number of measured particles and $\Delta \bar{D}$ is the experimental uncertainty associated with $\bar{D}$.

Assuming that overlap effect can be ignored, the volume fraction, $F_{\mathrm{v}}$, and number per unit volume, $N_{\mathrm{v}}$, of second phase particles were measured on thin foils applying the following equations [7]:

$$
\begin{gathered}
F_{\mathrm{v}}=\frac{\sum_{i=1}^{m} V_{i}}{A_{\mathrm{T}}(t+\bar{D})} \\
N_{\mathrm{v}}=\frac{m}{A_{\mathrm{T}}(t+\bar{D})}
\end{gathered}
$$

where $m$ is the total number of particles in the investigated region, $V_{i}$ is the volume of the $i^{\text {th }}$ particle, $A_{\mathrm{T}}$ is the area of the region, $t$ is the foil thickness and $\bar{D}$ is the average particle size. The $(t+\bar{D})$ factor arises from particles with centers outside the foil within $\bar{D} / 2$ of the top and bottom surfaces. Therefore equations (A.4) and (A.5) become:

$$
\begin{gathered}
F_{\mathrm{v}} \cong \frac{\sum_{i=1}^{m} V_{i}}{A_{\mathrm{T}} t}=\frac{\sum_{i=1}^{m} V_{i}}{V_{\mathrm{T}}} \text { when } \frac{t}{\bar{D}} \gg 1 \\
N_{\mathrm{v}} \cong \frac{m}{A_{\mathrm{T}} t}=\frac{m}{V_{\mathrm{T}}} \text { when } \frac{t}{\bar{D}} \gg 1
\end{gathered}
$$

where $V_{\mathrm{T}}$ is the volume of the region. The relative errors associated were calculated according to 
the following equations:

$$
\begin{gathered}
\Delta F_{\mathrm{v}}=\frac{\sum_{i=1}^{m} \Delta V_{i}}{V_{\mathrm{T}}}+F_{\mathrm{v}} \frac{\Delta V_{\mathrm{T}}}{V_{\mathrm{T}}} \\
\Delta N_{\mathrm{v}}=m \frac{\Delta V_{\mathrm{T}}}{V_{\mathrm{T}}}
\end{gathered}
$$

Carbides, sulphides and oxides generally have an ellipsoidal or spherical shape while nitrides have a prismatic shape. Taking into account equations (A.1) and (A.2), $V_{i}$ was calculated, in the case of an ellipsoidal shape, as:

$$
V_{i}=\frac{4 \pi}{3}\left(\frac{a_{i}}{2}\right)\left(\frac{b_{i}}{2}\right)^{2} \text { with } \Delta V_{i}=\frac{4 \pi}{3}(1 / 8)\left(2 a_{i} b_{i}+b_{i}^{2}\right) \Delta D_{i}
$$

In the case of a prismatic shape, $V_{i}$ was calculated as the volume of a parallelepiped with a square base:

$$
V_{i}=a_{i} b_{i}^{2} \text { with } \Delta V_{i}=\left(2 a_{i} b_{i}+b_{i}^{2}\right) \Delta D_{i}
$$

The volume of the thin foil region is:

$$
V_{\mathrm{T}}=l_{x} \cdot l_{y} \cdot t
$$

where $\left(l_{x} \cdot l_{y}\right)$ is the area of the investigated region $\left(\Delta l_{x}=\Delta l_{y} \cong \pm 10 \mathrm{~nm}\right)$ and $t$ the foil thickness. The foil thickness measured by the thickness fringes technique, $t^{\mathrm{tf}}$ is:

$$
t^{\mathrm{tf}}=(n+1 / 2) \xi_{(h k l)}
$$

where $\xi_{(h k l)}$ is the extinction distance of the matrix (i.e. $\alpha-\mathrm{Fe}$ ), $n$ is the number of grain boundary fringes in bright field and $h k l$ is the two beam diffraction vector. The estimated thickness error is $20 \%$.

When the electron transparent region did not allow observation of a grain boundary, the foil thickness was determined by the contamination spots method. Contamination spots with a conical shape were obtained by focusing the electron beam (STEM operating condition) on a tilted specimen, without activating the anticontamination device. The foil thickness $t^{\mathrm{cc}}$ was estimated, after tilting the contaminated specimen to zero degrees by the relationship:

$$
t^{\mathrm{cc}}=\frac{x}{\operatorname{tg} T}
$$

where $x$ is the mean distance of the double cone centres measured for different contamination points and $T=\left(30.0^{\circ} \pm 0.5^{\circ}\right)$ is the tilt angle. The error associated with $t^{\mathrm{cc}}$ calculation is:

$$
\Delta t^{\mathrm{cc}}=\frac{\Delta x}{\operatorname{tg} T}+\frac{x \Delta T}{\sin ^{2} T} \cong 10 \mathrm{~nm}
$$

However, the error can be larger when an oxide layer is formed on the specimen surface. In this case, the foil thickness is overestimated by $10 \mathrm{~nm}$ to about $50 \mathrm{~nm}$ [15]. 


\section{References}

[1] Haasen P., in "Physical Metallurgy", R.W. Cahn and P. Haasen Eds., Vol. 2 (North Holland Physics Publishing, 1983) p. 1376.

[2] Johnson H.H., Metal. Trans. A 19 (1988) 2371.

[3] Di Nunzio P.E. and Venditti D., Proceedings of "13th International Congress on Electron Microscopy", Paris, Vol. 1 (1994) p. 925.

[4] Cliff G. and Lorimer G.W., Proceedings of "5th European Congress on Electron Microscopy", Inst. Phys., London (1972) p. 140.

[5] Anelli E., in "Microscopia Elettronica in Trasmissione e Tecniche di Analisi di Superfici in Scienza dei Materiali", ENEA, Castro Marina (Le) (1985) p. 523.

[6] Underwood E.E., in "Quantitative Microscopy", R.T. DeHoff and F.N. Rhines Eds. (McGraw-Hill Book Company, New York, 1986) p. 149.

[7] Hirsh P.B., Nicholson R., Pashley D.W. and Whelan M.J., "Electron Microscopy of Thin Crystals", Butterworths, London (1965) p. 424.

[8] Di Nunzio P.E., Matera S. and Serventi A.M., Proceedings of "13th International Congress on Electron Microscopy", Paris, Vol. 2A (1994) p. 707.

[9] Di Nunzio P.E., "Development and Validation of Mathematical Models for Complex Carbide Precipitation During Hot Working and Continuous Annealing of Deep Drawing Steels", CSM Final Report, ECSC Agreement 7210-EC/401 (1994).

[10] Abbruzzese G., Acta Metall. 33 (1985) 1329.

[11] Abbruzzese G. and Lücke K., Acta Metall. 34 (1986) 905.

[12] Devanathan M.A.V. and Stachurski Z.O.J., Proc. Roy. Soc. A270 (1962) 90.

[13] Valentini R. and Solina A., Mater. Sci. Technol. 10 (1994) 908.

[14] Pressouyre G.M. and Bernstein I.M., Acta Metall. 27 (1979) 89.

[15] Rae D., Scott V.D. and Love G., Proceedings of "Quantitative Microanalysis with High Spatial Resolution", The Metal Society of London (1981) p. 57. 